\title{
The Middle-spotted Woodpecker Leiopicus medius in the Basque Country, Northern Spain: review of current ecological status
}

\author{
José María FERnÁNDEZ-GARCíA
}

Received: January 21, 2016 - Accepted: February 24, 2016

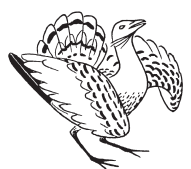

José María Fernández-García 2016. The Middle-spotted Woodpecker Leiopicus medius in the Basque Country, Northern Spain: review of current ecological status. - Ornis Hungarica 24(1): 42-54.

Abstract Despite previous inventories and atlas of the avifauna in the Basque Country, Northern Spain, the dense population of the Middle-spotted Woodpecker Leiopicus medius in the Izki forest was not discovered until the 1990's. This population mainly occupies a 3,700 ha Quercus pyrenaica forest, showing an average density of 0.89 territories $/ 10$ ha. The occurrence and abundance of territories is positively associated to the density of large caducifolious Quercus trees ( $>35 \mathrm{~cm}$ diameter). While nesting trees are apparently easily available, large trees for foraging could be a more limiting resource, given the historical exploitation regime of the forest. There are several other massifs in the region with smaller populations, but the functional connectivity, demographic and dispersal dynamics relating the core Izki and the peripheral areas have not been investigated. The conservation relevance of the Izki population in the Spanish context is high and given the need to understand the effects of forest management, future research should include spatial ecology, breeding performance as well as population monitoring.

Keywords: Picidae, Quercus pyrenaica, forest, Iberian Peninsula, conservation

Összefoglalás A korábbi madárfaunisztikai felmérések és a Baszkföldröl (Észak-Spanyolország) készült madártani atlasz ellenére csupán az 1990-es években írták le az Izki-i erdőben található, népes közép fakopáncs (Leiopicus medius) populációt. Ez a populáció egy 3700 hektáros, föleg pireneusi tölgyekből (Quercus pyrenaica) álló erdőben található, 0,89 territórium/ha sürüséggel. A territóriumok megoszlása pozitív összefüggést mutat a vastag törzsủ, lombhullató tölgyek ( $>35 \mathrm{~cm}$ átmérő) jelenlétével. Míg a fészkelésre alkalmas fák könnyen elérhetöek, addig a táplálkozásra szolgáló vastagabbak limitáló forrást jelenthetnek a sokéves erdőgazdálkodásnak tulajdoníthatóan. A térségben számos kisebb költöállomány is megtalálható, azonban az Izki-i populációval fennálló kapcsolatukat, demográfiai és terjedési dinamikájukat még nem vizsgálták. Az Izki-i populáció természetvédelmi jelentősége igen magas, és szükségessé teszi az erdőgazdálkodás hatásának feltérképezését. A jövőbeli kutatásoknak egyaránt tartalmaznia kell a faj ökológiájának, költésbiológiájának és populációdinamikájának felmérését.

Kulcsszavak: Picidae, pireneusi tölgy, erdőgazdálkodás, Ibériai-félsziget, természetvédelem

Hazi Foundation, 01192 Arkaute, Álava, Spain,e-mail: jofernandez@hazi.es

\section{Introduction}

The Middle-spotted Woodpecker Leiopicus medius is nearly endemic in the Western Palearctic, from European Russia and the Caucasus, to France and the Iberian Peninsula (Gorman 2014). The nominate race is distributed across continental Europe, as the formerly described Iberian race lilianae is not currently recognized (Gorman 2004). This woodpecker is a resident of temperate forests, strongly preferring mature oak woodlands. It also inhabits mixed deciduous and riparian forests, parklands, wooded pastures and even beech stands, provided 
the availability of standing large, decaying and rough-barked trees (Pasinelli 2003). The oak volume and the number of suitable trees for foraging $(>35 \mathrm{~cm}$ girth) and nesting $(>20$ $\mathrm{cm}$ girth) have been related to patch occupancy, colonization and persistence. The overall long-term trend is declining, because the species is sensitive to the general fragmentation of the original lowland oak forests in Europe (Lammertink 2014). More recently, various trends and moderate increases have been reported for core Central European countries, and the conservation status proposed by the IUCN Red List is "least concern", both globally (BirdLife International 2012) and regionally in the European Union (BirdLife International 2015). In spite of this, small, isolated and peripheral populations face an increased risk of extinction (Pasinelli 2003).

Northern Spain holds the westernmost population of the species. It encompasses the main mountain ranges, namely the Cantabrians, the Basque and the Pyrenees. These form an 800 $\mathrm{km}$ long, W-E oriented corridor. Although traditionally exploited, degraded and reduced in their original surface, oak (Quercus pyrenaica, Q. faginea, Q. robur and Q. petraea) forests remain mainly at altitudes between 700 and $1300 \mathrm{~m}$, with lowland forests showing a much more relict and patchy occurrence. Three separate populations of the Middle-spotted Woodpecker are known in Northern Spain. The Cantabrian is located in the provinces of Asturias, Cantabria, León and Palencia, and its extent of occurrence (sensu IUCN 2014) covers

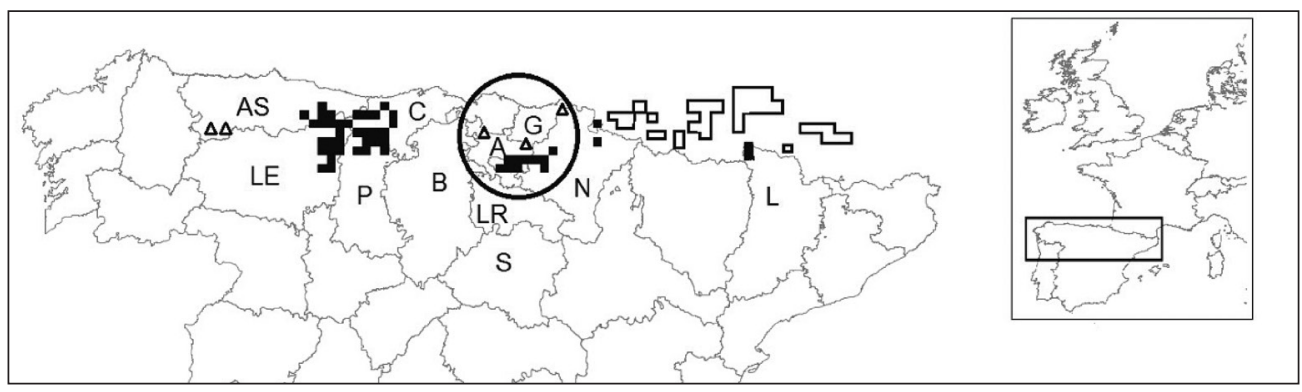

Figure 1. Current distribution of the Middle-spotted Woodpecker Leiopicus medius in Spain, during breeding period. Presence recorded in UTM $100 \mathrm{~km}^{2}$ squares, updated from Onrubia et al. (2003). Black squares indicate confirmed presence; triangles, old, possible or unconfirmed presence. The area of the population in the Basque Country and neighbouring districts is circled. Borders of Spanish provinces are delineated. Those mentioned in the text are signaled: AS - Asturias, LE - León, P - Palencia, C - Cantabria, B - Burgos, A - Álava, G - Gipuzkoa, $\mathrm{N}$ - Navarre, LR - La Rioja, S - Soria and L - Lérida. The UTM $100 \mathrm{~km}^{2}$ squares in the northern (French) section of the Pyrenees closer to the Spanish border, with confirmed presence during breeding periods 2009-2012 (Issa \& Muller 2015), are also shown (empty squares)

1. ábra A közép fakopáncs (Leiopicus medius) jelenlegi spanyolországi költési elterjedése. Az előfordulás feltérképezése 100 km²-es UTM négyzetekben készült, Onrubia et al. (2003) nyomán. A fekete négyzetek jelentik a megerősített előkerülést, míg a háromszögek a lehetséges régi vagy nem megerősített előkerülést mutatják. A körön belül találhatóak a baszkföldi és az azt körülvevő populációk. A határvonalak a spanyol tartományokat jelölik. A szövegben említett és az ábrán jelölt tartományok a következők: AS - Asturias, LE - León, P - Palencia, C - Cantabria, B - Burgos, A - Álava, G - Gipuzkoa, N - Navarre, LR - La Rioja, S - Soria and L - Lérida. A Pireneusok Franciaország-felőli részére eső UTM négyzetek (közel a spanyol határhoz) a 2009-2012 közötti költési időszaki megkerülések adatait mutatják (üres négyzetek, Issa \& Muller 2015) 
around 35 squares of $100 \mathrm{~km}^{2}$. A subpopulation in the western section of the Cantabrians has probably gone extinct in the last decade (Sánchez et al. 2009). As for the Pyrenees, two subpopulations are known from the provinces of Lérida and Navarre respectively, with a joint extent of occurrence of just 5 squares of $100 \mathrm{~km}^{2}$ (Onrubia et al. 2003). In fact, these Pyrenean subpopulations are possibly connected to the population of the Northern (French) slope of the range, where the species is more widely distributed (Issa \& Muller 2015).

Finally, the Basque population lays at an intermediate geographic position between the above mentioned, c. $125 \mathrm{~km}$ distant to the closest limits depicted for the Cantabrian and 60 $\mathrm{km}$ for the Pyrenean. It is found in the province of Álava and the adjacent fringes of Nararre and Burgos (González et al. 2006), and covers an extent of occurrence of 10 squares of $100 \mathrm{~km}^{2}$ (Onrubia et al. 2003) (Figure 1). This population is highly relevant from a conservation perspective. In the Spanish context, because it contains the densest population thriving in a continuous, unfragmented forest block (the Izki forest) and it holds at least one third of the country's numbers, even though figures available for the Cantabrian are partial and not completely comparable (García-Fernández et al. 2002, Robles \& Olea 2003, Fernández \& Lozano 2009, Fombellida et al. 2009); and globally, because populations at the edge of the distribution may represent local adaptations, distinct evolutionary potential and ability to persist under rapidly changing climatic scenarios (Hampe \& Petit 2005, Fuller et al. 2011, Rehm et al. 2015). In this paper, I review and synthesize the discovery, inventory, research and current state of knowledge about this population.

\section{Historical background and discovery}

Apparently, there is no specifically attributable mention of the Middle-spotted Woodpecker in the classical Spanish literature (Bernis 1995). Popular, vernacular names have not been described either, the species presence being covered by the much more common and abundant Great-spotted Woodpecker Dendrocopos major (Bernis 1995, García-Fernández 2008) The scientific inventory of the avifauna in Spain is quite recent in historical terms, if compared to central and northern European countries. The first systematic approaches date back to the late $19^{\text {th }}$ century, when the catalogues by Ventura Reyes and José Arévalo were published. Ornithological contributions at this stage were highly influenced by visiting naturalists and ornithologists, like Alfred Brehm, Howard Saunders and Howard Irby (Tellería 2004).

Reig (2004) and Salas et al. (2005) have compiled and reviewed critically the existing historical records on the occurrence of the Middle-spotted Woodpecker in the Iberian Peninsula. The reliable data - detailed observations or descriptions of museum specimens - are referred to the Catalan Pyrenees $(1879,1913)$ and the Cantabrians $(1876,1921)$, apart from northern Portugal (1896) and other Spanish regions where the records are considered doubtful (central Spain) or simply erroneous (southern Spain). Among historical authors, Witherby (1922) provided certain information on the Cantabrian population, and captured eight specimens, that based the already mentioned proposal of the subspecies Dryobates medius lilianae. The question whether the Middle-spotted Woodpecker had a wider distribution in the $19^{\text {th }}$ century than today remains open, given the evidences from northern Portugal. 
Regarding the Basque-Navarre mountain range, the Middle-spotted Woodpecker was not mentioned by foreign ornithologists visiting the region, although this part of the country did not attract as much interest as southern Spain. Saunders (1884), Chapman and Buck (1893), Gadow (1897), Blasius (1907) and Ticehurst and Whistler (1925) explored several forested areas, especially in Navarre, but found no record on this species, unlike other less cryptic woodpeckers (e.g. Black Woodpecker Dryocopus martius). The first mention is credited to Aldaz (1918), who just noted the "rare" occurrence of the species. Despite vague, it may be reliable because his catalogue and descriptions are well founded, based on collections (although apparently this was not the case for the Middle-spotted Woodpecker) (Sansinenea 1908). None of the Spanish populations of the species produced new substantial information until the pioneer study by Purroy et al. (1984) in the Cantabrians. As for the Basque region, the only worthwhile was Noval (1967) who stated "few observations and not completely reliable". In Navarre, Purroy (1974) knew an only occupied locality, but better ascribed to the Pyrenean range than to the Basque.

During 1975-1977, field efforts to map the distribution of breeding bird populations in the southern third of the Basque Country - and neighboring regions, namely La Rioja, Burgos and Soria - were undertaken by De Juana (1980). He authored a pioneering atlas, but obtained no records for the Middle-spotted Woodpecker.

The first systematic mapping of the breeding bird populations in the Basque Country and Navarre were performed in years 1982-1984, using conventional atlas methodology and the $100 \mathrm{~km}^{2}$ squares of the Universal Transverse Mercator (UTM) grid as sampling units. The entire region was covered, but the Middle-spotted Woodpecker was recorded in just two locations. Although no specific census was made, regional population size was estimated less than 10 pairs on account of the scarcity of observations, and distance from the known areas for the Cantabrian and the Pyrenean (French) populations suggested isolation and an endangered status (Elósegui 1985, Faus 1985).

In the early 1990's, Arambarri and Rodríguez (1994) communicated the presence of the species in a new location in the province of Álava. In this case, records were regular and suggested a well-established population. After their discovery, in May-June 1994 and 1995, these authors performed a more systematic census, sampling $Q$. pyrenaica and $Q$. faginea forest patches over a total area of 17 UTM $100 \mathrm{~km}^{2}$ squares, by means of 387 point counts along pre-fixed itineraries, where play-back was used (Arambarri \& Rodríguez 1996). Occurrence of the Middle-spotted Woodpecker was demonstrated in five of those squares, concentrated in and around the so-called Izki forest. This is a vast woodland of nearly 7,000 ha, dominated by Q. pyrenaica (3,700 ha), Q. faginea (900 ha) and beech Fagus sylvatica $(1,800 \mathrm{ha})$. Density in the Izki forest was $1.29 \pm 0.12$ pairs/10 ha, assuming that birds responded to the tape from a maximum distance of $150 \mathrm{~m}$. The population size was estimated $451 \pm 42$ pairs, including birds from the close Sabando forest, a patch of nearly 450 ha dominated by $Q$. pyrenaica.

The fact that this population had gone previously unnoticed, contrasts sharply with its shown local abundance, the conspicuousness of the birds at occupied sites and the relatively good knowledge about the regional avifauna. The participants in the 1982-1984 atlas probably mistook observations of the unexpected Middle-spotted Woodpecker for the 
Great-spotted, which was frequent in all sorts of forest landscapes and also inhabited the Izki forest at that time (Faus 1985). Gainzarain (2006) pointed out that, decades ago, under a more intensified forest exploitation regime, the Middle-spotted Woodpecker density could be lower, thus preventing detection. But this idea is hard to apply, because the systematic approaches to the description of the regional avifauna began in the late 1970's and deepened in the 1980's, as seen above. This period is not that far from the discovery of the population, and encroachment of the forest as a consequence of rural emigration to cities had already begun in the 1950's (Michel \& Gil 2013).

\section{Distribution}

Since the discovery of the Izki population, two systematic studies on the distribution, covering the whole Basque region, were performed. The first one took place in 1995 and was focused on the Picidae assemblage (Lanius Ornithological Society et al. 1995). The Middle-spotted Woodpecker was searched for in 27 UTM $100 \mathrm{~km}^{2}$ squares that held a significant surface of caducifolious Quercus patches. Occurrence was only noted for seven squares, spread over the already known Izki population and the western tip of Gipuzkoa province, bordering Navarre. Nevertheless, in this latter sector, records of the species were not definitely confirmed.

The second systematic survey was performed in the framework of the Spanish atlas of breeding birds during 1998-2001, and again every UTM $100 \mathrm{~km}^{2}$ square was surveyed using non-specific atlas methodology. Ten squares were found occupied by the Middle-spotted Woodpecker, six of them in Álava - the Izki forest being the core - and four in neighboring areas of Navarre (Onrubia et al. 2003). The species went unrecorded from the squares in Gipuzkoa province where the 1982-1984 atlas and the 1995 survey had signaled it.

While the study by Onrubia et al. (2003) is the most recent systematic, extensive approach to the breeding distribution of the population, the picture was still not complete. Two additional populations have been reported in the last decade, from locations where the occurrence of the species was previously unknown. The first one (Montes de Vitoria range) was surveyed in detail, by means of 58 point counts over a total surface of 610 ha of oak patches, interspersed among a forest matrix of beech stands and coniferous plantations (Unanue et al. 2010). The number of occupied patches was small (14\% of positive point counts). The second population (Sierra de Entzia range) has not been investigated yet, but the presence of territorial individuals has been well established over the years 2013-2015 (J. M. Fernández-García, own data). These two populations are not contiguous to the Izki core population, but in fact functional connectivity among them is probable, because despite the fragmentation of the oak patches, the forest matrix is continuous and distances to the closest boundaries are less than $15 \mathrm{~km}$. This length is within reach for a short-distance natal disperser like the Middle-spotted Woodpecker (Pasinelli 2003).

Even with such intensity of sampling at regional scale, there are three distinct forest massifs where the occurrence of the species has been cited in the past, but which lack reliable evidences about the presence of a permanent breeding population. The first one is the 
eastern tip of Gipuzkoa province: surveys in 1982-1984 and 1995 communicated few and unconfirmed records (see above); the one in 1998-2001 did not. During March-May 2015, the best oak habitat patches remaining in six wider areas of Gipuzkoa have been sampled by means of point counts. Just one territory (i.e. a locality where individuals were detected on two visits) was assessed, apart from other two unrepeated records. Therefore, current distribution and population size in Gipuzkoa province appears to be certainly small or even anecdotic (Itsas Enara Ornithological Society 2015).

The other two massifs with previous records lay both in Álava. Opportunistic observations (Elguea-Urkilla range, 1994, Gorbea range, 2006 and 2007) by skilled observers were communicated, and more ambitious surveys have taken place thereafter. However, occupied territories or even isolated birds have not been recorded again (J. M. Fernández-García own data, Unanue et al. 2014), in spite of the availability of suitable and large patches of oak habitat. Structural connectivity could play a role in explaining the absence, because these forest patches are either too far from the closest known population $(40 \mathrm{~km})$ or separated by broad $(5-7 \mathrm{~km})$ cultivated areas that could act as barriers, thus preventing dispersal. Temporal occupancy, inter-annual variability as well as local colonization and extinction processes have been documented for the Cantabrian population of the Middle-spotted Woodpecker (Robles \& Ciudad 2012), and tentatively could explain out-of-range records.

Post-breeding (wintering) distribution of bird populations in Álava province was assessed in 2002-2005. Linear transects were performed in every UTM $100 \mathrm{~km}^{2}$ squares during December-January, applying non-specific methodology. As for the Middle-spotted Woodpecker, a map of occurrence and relative abundance was built, which showed a similar range than the breeding period and absence over areas other than the Izki forest and its surroundings (Gainzarain 2006). Therefore, at the mentioned sampling scale, the resident status of the population was evident.

\section{Density and population size}

The census by Arambarri and Rodríguez (1996) was the first to quantify the abundance of the Izki population. In 2000, breeding bird assemblages were investigated at Izki, counting individuals along transects totalizing $2.02 \mathrm{~km}$ across $Q$. pyrenaica patches and $1.36 \mathrm{~km}$ across $Q$. faginea patches (Onrubia et al. 2001). The average Middle-spotted Woodpecker densities were estimated at $1.7 \mathrm{birds} / 10$ ha $(Q$. pyrenaica woodland) and 0.3 birds $/ 10$ ha (Q. faginea woodland). For comparison, this same study measured abundance of sympatric Great-spotted Woodpecker at $0.2-0.3$ birds/10 ha. But the Middle-spotted Woodpecker numbers were later criticized by Robles and Olea (2003), based on invalid methodological assumptions, which probably led to overestimate the population density. Authors of previous censuses had used long emissions of tape vocals, considered $150 \mathrm{~m}$ as the maximum attracting range, concentrated their fieldwork in May and June during the incubation and chick-rearing periods, did not separate territorial males and females, and did not acknowledge floaters or dispersing birds. These aspects have been highlighted by Berndt (2009) as potential sources of overestimation of local Middle-spotted Woodpecker population size. 
No other attempts to census the Izki population have been made until 2012, when Ciudad and Robles (2014) estimated population size by mapping territories in 37 parcels (30 ha each), selected randomly. Surveyed area was around $16 \%$ of the forested surface of Izki, and nearly $25 \%$ of the oak woodland, therefore meaning a robust sample. Parcels were visited 3-5 times during pre-breeding period (March-April), when birds showed a peak in territorial behavior. Each parcel was sampled in detail by one skilled observer, at a rate of $20 \mathrm{ha} /$ hour. Every 100 m, vocalizations were emitted during 30 seconds. If Middle-spotted Woodpeckers were detected, the position, activity and movement of the birds were mapped. Territories per parcel were delimited based on repeated detections and interactions among birds, rejecting cases of vagrancy and territories with a minor surface inside the parcel. Average woodpecker density in the Pyrenean oak forest was 0.89 territories/10 ha (95\% CI: 0.74 1.04), which yielded a global estimation of 338 territories (280-396) for the entire study area. Densities of $0.2-0.6$ territories/10 ha have been measured in the Cantabrian range (Robles \& Olea 2003, Fombellida et al. 2009), and 0.3-0.6 territories/10 ha in the Pyrenees (Camprodon et al. 2009). Therefore, densities at Izki forest outnumber those reported for other Spanish populations, and approach those for Central Europe (Pasinelli 2003), but we must take into account that differences in methodology may prevent reliable comparisons.

\section{Habitat use and selection}

The breeding habitat of the Izki population was described for the first time by Arambarri and Rodríguez (1997). They parameterized forestry variables (dominance, coverage, number and dimension of trees, regeneration) in four plots of $50 \mathrm{~m}$ diameter, centered in trees with known nests. Q. pyrenaica was the dominant tree species (80-90\%) in three plots, and F. sylvatica (62\%) in the remaining. Main accompanying shrubs were Ilex aquifolium, Crataegus monogyna and Malus sylvestris. Average volume of wood was $189 \mathrm{~m}^{3} / \mathrm{ha}$ (167-207).

A more focused research was performed by Maldonado et al. (2009). The forest structure was characterized along nine transects $200 \times 8 \mathrm{~m}$, ascribed to patches occupied and unoccupied by Middle-spotted Woodpeckers, where species of trees, diameter, height, sanitary state, age and dead wood were measured. Transects "with" woodpeckers showed less density of trees, higher numbers of trees $>50 \mathrm{~cm}$ diameter $(12-50 /$ ha vs. none) and snags $>20 \mathrm{~cm}$ (6-90 vs. none), higher average diameters (31 cm vs. 21$)$, older age ( $>130$ years vs. $<100$ ), higher diversity of tree sizes tending to irregular structure, and a marginally higher volume of logs and dead wood on the ground. Statistical tests were not applied in this study, and the Middle-spotted Woodpecker presence-absence patch classification was questionable, based on old (year 1994), indirect or non-systematic information. However, the use of mature to intermediate forest structures - or at least harbouring big caducifolious trees - was evident.

Ciudad and Robles (2014) described habitat selection during breeding, searching for correlations between presence and abundance of territories in 37 parcels (30 ha each; see above) and a number of structural variables (number, height, health condition and holes regarding trees $>9,5 \mathrm{~cm}$ diameter), parameterized in 330 circular plots $(0,04$ ha each) regularly distributed inside the parcels. Generalized linear models (GLM) and multiple linear 
regressions (LM) were applied. The occurrence and density of Middle-spotted Woodpecker territories were positively associated to density of large caducifolious Quercus trees (> 35 $\mathrm{cm}$ diameter); on average there were 65 such trees inside occupied parcels vs. 15 in unoccupied ones. But this influence was not detected for potential nesting trees $(>17 \mathrm{~cm}$ and decaying). Authors suggested that foraging trees acted as a limiting resource for the population, unlike nesting trees which seemed much more available. This feature was possibly a consequence of the history of coppice exploitation of the forest, which originated stands with high competence among regenerating trees.

Apart from the landscape and parcel scales, habitat selection has been investigated at the nesting-tree scale. Arambarri and Rodríguez (1997) described six trees that had been used for breeding. Five of them were Q. pyrenaica and just one F. sylvatica, but all were damaged or presented dead parts. Holes had been excavated at 1.1-5.4 m height. No orientation preference was observed. Maldonado et al. (2009) characterized in detail 26 nesting trees and plots $15 \mathrm{~m}$ diameter around each one of them, although the unambiguous attribution of such holes to Middle-spotted Woodpecker was not verified in the field. They found that the density of trees within the plot was lower than the average in the patch, and that frequency of holes excavated on damaged or dead trees was seven times higher than those on apparently healthy trees $\left(\chi^{2}, \mathrm{p}<0.01\right)$. Also, a clear preference for trees colonized by the fungus Fomes fomentarius was reported: nearly half of the trees in the forest with fungi had been excavated $\left(\chi^{2}, \mathrm{p}<0.01\right)$. Diameter range for nesting trees was $20-50 \mathrm{~cm}$, but the average diameter $(33.7 \mathrm{~cm})$ was larger $(t$ test, $p<0.01)$ than the average tree within the patch. Nest height above ground varied between 1 and $14 \mathrm{~m}$. Finally, there was a trend to increase the number of holes with the intensity of damage in the trees, from healthy to decaying and dead.

In turn, Ciudad and Robles (2014) described physical characteristics of 28 trees (all $Q$. pyrenaica) with holes known to have been used by Middle-spotted Woodpeckers for nesting. Mean height of the hole was $4.5 \mathrm{~m}$ (range 1.5-10.5), and entrance was biased towards S-SE. Average diameter of the nesting tree was $33.8 \mathrm{~cm}$ (range 18.5-53.2). These parameters were compared for each nesting tree with the three closer trees, by means of generalized linear mixed models (GLMM). Best model associated nesting to tree condition (i.e. health), presence of fungus and of previous holes, either natural or excavated.

Post-breeding habitat use has received little attention. But basically, no relevant differences compared to the breeding period have been reported. Domínguez and Onrubia (2004) found a positive selection for patches with high $Q$. pyrenaica coverage and mature stands, also exhibiting a rich substrate of fruiting shrubs (I. aquifolium and C. monogyna). Gainzarain (2006) confirmed the extensive use of the $Q$. pyrenaica woodland, and much weaker abundance in certain open $Q$. faginea patches.

\section{Breeding biology}

Six breeding attempts monitored by Arambarri and Rodríguez (1997) rendered estimated laying dates between April 27-28 and May 10-11. One adult stayed with the chicks inside the hole until they were 12 days old. From day 16, chicks were generally fed at the entrance of the hole. 
Ciudad and Robles (2014) calculated laying date for two broods at Izki forest: May 9 and 12. Breeding success (proportion of nests with at least one fledgling) was $70 \%(\mathrm{~N}=10)$, with losses from predation by carnivorous mammals and D. major. Mean fledging date was June 9 (range May 31-June 22, N=7) and average number of fledglings per nest was 2.2 (range $1-3, N=5)$. This parameter does not depart from the Cantabrian population (H. Robles \& C. Ciudad, in litt.), but is low if compared to the core of the European distribution $(4.1 \pm 1.4$ from four studies) (Pasinelli 2006).

\section{Diet}

Information on this topic is rather anecdotic. Only Arambarri and Rodríguez (1997) recorded feeding activities $(\mathrm{N}=204)$ from two nests. They observed an increase in feeding frequency with age of chicks (Kruskal-Wallis test, $\mathrm{p}<0.01$ ). The most important preys were Hymenoptera (32\% of feedings) and Coleoptera (22\%). A high relevance of common ivy Hedera helix berries was noted in one of the nests $(42 \%)$, with lower in the other $(4 \%)$. The presence of ivy in Middle-spotted Woodpecker diet has generally been undervalued (Pasinelli 2003, Spülher et al. 2015), but could compensate low availability of insects during energetically demanding periods, like brood-rearing (Froehlich-Schmitt 2015).

\section{Concluding remarks}

It is surprising that the dense population of Izki was not discovered until the 1990's, given the relatively good knowledge about the regional avifauna. Possibly, ornithologists focused their attention on more attractive or fashionable groups, such as waterbirds, raptors and migrants, which were already subject to monitoring programs. Forest birds in general and woodpeckers in particular could be overlooked, despite the fact that they are a dominant component of most bird assemblages in the Basque Country (Galarza 1996). Again, unknown smaller populations have been described in the 2000's, although in these cases it is not clear whether the reason could be a recent colonization of new forest massifs by the core Izki population. On the contrary, we've witnessed recent and inconclusive efforts to confirm the situation in other areas where the species was recorded in the past.

Interpretation of this picture should take into account spatial ecology, functional connectivity and demography. In the Cantabrian range, persistence of the species on forest patches was related to habitat structure and fragmentation, but also to the size of the local population (Robles \& Ciudad 2012). Unluckily, research on Izki has only focused on topics that are essential to estimate the conservation status (census and monitoring) and to design compatible forest exploitation practices (habitat selection). But clearly, understanding the dynamics in the core Izki population and the peripheral forest massifs requires new research priorities. For instance, survival, dispersal and habitat preference of juveniles are important to estimate colonization-extinction rates in suboptimal habitat patches and genetic exchange among subpopulations (Robles et al. 2008). 
Knowing the reproductive output is key to estimate the impact of forest management on habitat quality and population fitness, because density indicators maybe buffered by demography. Compared to Central European populations, breeding parameters in Spanish Middlespotted Woodpecker populations show lower values, and that could also apply to the Basque Country (Ciudad \& Robles 2014), but sample sizes reported are too small. From a global perspective, the marginal position of the Spanish populations is important to determine genetic conservation units and to decide their relevance for the species conservation in a context of environmental change.

\section{Acknowledgements}

I benefited from ideas and comments by Carlos Ciudad, José Antonio Gainzarain, Ana Gracianteparaluceta, Gilberto Pasinelli, Hugo Robles, Jonathan Rubines, Azaitz Unanue, the rangers of Izki Natural Park and two anonymous reviewers. This paper is a contribution to LIFE 10/NAT/ES/0572, co-funded by the European Commission and the Provincial Council of Álava.

\section{References}

Aldaz, J. 1918. Catálogo de las aves observadas en Guipúzcoa y Vizcaya [Catalogue of birds observed in Guipúzcoa and Vizcaya]. - Memorias de la Real Sociedad Española de Historia Natural 10: 459-508. (in Spanish)

Arambarri, R. \& Rodríguez, A. 1994. Presencia en época reproductora de pico mediano (Dendrocopos medius) en Álava [Presence of the Middlespotted Woodpecker (Dendrocopos medius) during the breeding season in Álava]. - Ardeola 41: 100-101. (in Spanish)

Arambarri, R. \& Rodríguez, A. 1996. Distribución y estima poblacional del pico mediano Dendrocopos medius en Álava [Distribution and population estimates of Middle-spotted Woodpecker Dendrocopos medius population in Álava]. Ardeola 43: 221-223. (in Spanish with English Summary)

Arambarri, R. \& Rodríguez, A. 1997. Selección del hábitat de nidificación y análisis del espectro alimenticio del pico mediano (Dendrocopos medius) en el marojal de Izki [Nesting habitat selection and analysis of the nutritional spectrum of the Middle-spotted Woodpecker (Dendrocopos medius) in the oak forest of Izki]. - Unpublished report (in Spanish)

Berndt, R. K. 2009. Responses of Middle-spotted Woodpecker Dendrocopos medius to playback in course of population surveys in
Schleswig-Holstein (North Germany). - Vogelwelt 130: 91-98.

Bernis, F. 1995. Diccionario de nombres vernáculos de aves [Dictionary of vernacular names of birds]. - Gredos, Madrid (in Spanish)

BirdLife International 2012. Leiopicus medius. - The IUCN red list of threatened species. - http://www. iucnredlist.org. Downloaded on December 2015.

BirdLife International 2015. European red list of birds. - Office for Official Publications of the European Communities, Luxembourg

Blasius, R. 1907. Die Pyrenaen und ihre vogelwelt [The Pyrenees and its birdlife]. - Proceedings of the $4^{\text {th }}$ International Ornithological Congress, Dulau \& Co., London, pp. 554-579. (in German)

Camprodon, J., Faus, J. \& Soler, J. 2009. Ecologia i conservació dels pícids (Picidae) a la Val d'Aran [Ecology and conservation of picids (Picidae) in the Val d'Aran]. - Unpublished report (in Catalan)

Chapman, A. \& Buck, W. J. 1893. Wild Spain. - Gurney \& Jackson, London

Ciudad, C. \& Robles, H. 2014. Population size and habitat selection of the Middle-spotted Woodpecker (Dendrocopos medius) in Izki Natural Park: results of the LIFE+ Pro-Izki project. - In: Fernández-García, J. M., Pasinelli, G., Robles, H. \& Rubines, J. (eds.) $-7^{\text {th }}$ International Woodpecker Conference, Book of Abstracts, p. 9. Diputación Foral de Álava, Vitoria 
De Juana, E. 1980. Atlas ornitológico de La Rioja [Ornithological Atlas of La Rioja]. - Instituto de Estudios Riojanos, Logroño (in Spanish)

Domínguez, J. \& Onrubia, A. 2004. Caracterización y uso del hábitat por el pico mediano (Dendrocopos medius L.) durante el periodo postreproductor en el Parque Natural de Izki (Álava) [Characterization and habitat use by the Middle-spotted Woodpecker (Dendrocopos medius L.) during the post-reproductive period in the Natural Park of Izki (Álava)]. $-17^{\text {th }}$ Spanish Ornithological Congress. Book of Abstracts, p. 195. SEO/BirdLife, Madrid (in Spanish)

Elósegui, J. 1985. Navarra. Atlas de aves nidificantes [Navarra. Atlas of breeding birds]. - Caja de Ahorros de Navarra, Pamplona (in Spanish)

Faus, J. M. 1985. Atlas de las aves nidificantes de Álava, Vizcaya y Guipúzcoa [Atlas of breeding birds of Álava, Vizcaya and Guipúzcoa]. - In: Álvarez, J., Bea, A., Faus, J. M., Castién, E. \& Mendiola, Í. (eds.) Atlas de los vertebrados continentales de Álava, Vizcaya y Guipúzcoa (excepto Chiroptera) [Atlas of terrestrial vertebrates of Álava, Vizcaya and Guipuzcoa (except Chiroptera)]. - Gobierno Vasco, Bilbao, pp. 101-267. (in Spanish)

Fernández, Á. \& Lozano, F. 2009. Censo y caracterización del hábitat del pico mediano (Dendrocopos medius) en el Parque Nacional Picos de Europa [Census and habitat characterization of the Middle-spotted Woodpecker (Dendrocopos medius) in the Picos de Europa National Park]. - Locustella 6: 89-101. (in Spanish)

Fombellida, I., García, A. \& Rollán, M. 2009. Cantabria es el principal refugio ibérico del pico mediano [Cantabria is the main Iberian refuge of the Middle-spotted Woodpecker]. - Quercus 275: 14-20. (in Spanish)

Froehlich-Schmitt, B. 2015. Efeubeeren Hedera helix als nestlingsnahrung des Mittelspechts Dendrocopos medius [Common ivy Hedera helix as food for Middle-spotted Woodpecker Dendrocopos medius nestlings]. - Ornithologischer Beobachter 112: 203-210. (in German with English Summary)

Fuller, R. A., Ladle, R. J., Whittake, R. J. \& Possingham, H. P. 2011. Planning for persistence in a changing world. - In: Ladle, R. J. \& Whittaker, R. J. (eds.) Conservation Biogeography. Wiley-Blackwell, Oxford, pp. 163-189.

Gadow, H. 1897. In Northern Spain. - Adam and Charles Black, London

Gainzarain, J. A. 2006. Atlas de las aves invernantes en Álava (2002-2005) [Atlas of wintering birds in Álava (2002-2005)]. - Diputación Foral de Álava, Vitoria (in Spanish)
Galarza, A. 1996. Evolución espacio-temporal de la avifauna del País Vasco [Spatiotemporal evolution of the avifauna of the Basque Country]. Universidad del País Vasco, Bilbao (in Spanish)

García-Fernández, J., Álvarez, E. \& Falagán, J. 2002. El pico mediano en la provincia de León: cambios en la distribución y tamaño poblacional [The Middle-spotted Woodpecker in León province: changes in distribution and size population]. Ecología 15: 335-342. (in Spanish with English Summary)

García-Fernández, J. 2008. Pico mediano Dendrocopos medius [Middle-spotted Woodpecker]. - In: García-Fernández, J., Ramos, L. A. \& Vázquez, X. (eds.) Atlas de las aves reproductoras de León [Atlas of breeding birds of León]. - Diputación de León, León, pp. 157-158. (in Spanish)

González, D., Román, F., Fernández, R. \& Lobo, J. L. 2006. Anuario ornitológico de la provincia de Burgos [Ornithological yearbook of the province of Burgos]. Vol. I. - Caja de Burgos, Burgos (in Spanish)

Gorman, G. 2004. Woodpeckers of Europe. A study of the European Picidae. - Bruce Coleman, London

Gorman, G. 2014. Woodpeckers of the world. The complete guide. - Christopher Helm, London

Hampe, A. \& Petit, R. 2005. Conserving biodiversity under climate change: the rear edge matters. - Ecology Letters 8: 461-467. DOI: 10.1111/j.1461-0248.2005.00739.x

Issa, N. \& Muller, Y. 2015. Atlas des oiseaux de France métropolitaine: nidification et présence hivernale [Atlas of birds in France: nesting and winter presence]. - LPO/BirdLife \& SEOF, Paris (in French)

Itsas Enara Ornithological Society 2015. Distribución del pico mediano en Gipuzkoa [Distribution of the Middle-spotted Woodpecker in Gipuzkoa]. Unpublished report (in Spanish)

IUCN 2014. Guidelines for using the IUCN red list categories and criteria. Version 11. Standards and Petitions Subcommittee. - http://www.iucnredlist.org. Downloaded on December 2015.

Lammertink, M. 2014. Trends in threat status and priorities in conservation of the woodpeckers of the world. - Acta Ornithologica 49: 207-219. DOI: 10.3161/173484714X687109

Lanius Ornithological Society, Itsas Enara Ornithological Society \& Hontza Ornithological Society 1995. Los Picidae en la CAV [The Picidae in the CAV (Basque Autunomous Community)]. - Unpublished report (in Spanish)

Maldonado, C., Martínez de Arano, I. \& Quintana, E. 2009. Caracterización del hábitat de Dendrocopos medius L. (pico mediano) en el marojal 
de Izki. Dinámica forestal y gestión tradicional [Habitat characterization of the Dendrocopos medius L. (Middle-spotted Woodpecker) in the oak forest of Izki. Traditional forest dynamics and management]. $-5^{\text {th }}$ Spanish Forestry Conference, Spanish Society of Forestry Science, Ávila (in Spanish)

Michel, M. \& Gil, L. 2013. La transformación histórica del paisaje forestal en la Comunidad Autónoma de Euskadi [The historical transformation of the forest landscape in the Basque Country]. Gobierno Vasco, Vitoria (in Spanish)

Noval, A. 1967. Estudio de la avifauna de Guipúzcoa [Study of the avifauna of Guipúzcoa]. - Munibe 19: 5-78. (in Spanish)

Onrubia, A., Robles, H., Salas, M., González-Quirós, P. \& Olea, P. 2003. Pico mediano Dendrocopos medius [Middle-spotted Woodpecker]. - In: Martí, R. \& Del Moral, J. C. (eds.) Atlas de las aves reproductoras de España [Atlas of breeding birds of Spain]. - Ministerio de Medio Ambiente, Madrid, pp. 358-359. (in Spanish)

Onrubia, A., Sáenz de Buruaga, M., Campos, M. Á. \& Balmori, A. 2001. Estudio faunístico del Parque Natural de Izki (Álava) [Fauna study of the Natural Park of Izki (Álava)]. - Unpublished report (in Spanish)

Pasinelli, G. 2003. Middle-spotted Woodpecker Dendrocopos medius. - BWP Update 5: 49-99.

Pasinelli, G. 2006. Population biology of European woodpecker species: a review. - Annales Zoologici Fennici 43: 96-111. DOI: 10.5167/uzh72663

Purroy, F. J. 1974. Fauna navarra en peligro de extinción [Endangered wildlife of the Navarra fauna]. - Ediciones y Libros, Pamplona (in Spanish)

Purroy, F. J., Álvarez, Á. \& Pettersön, B. 1984. La población de pico mediano Dendrocopos medius (L) de la Cordillera Cantábrica [The Cantabrian population of Middle-spotted Woodpecker Dendrocopos medius (L)]. - Ardeola 31: 81-90. (in Spanish with English Summary)

Rehm, E. M., Olivas, P., Stroud, J. \& Feeley, K. J. 2015. Losing your edge: climate change and the conservation value of range-edge populations. - Ecology and Evolution 5: 4315-4326. DOI: $10.1002 /$ ece 3.1645

Reig, A. 2004. El descubrimiento del pico mediano en León y algunas notas sobre su presencia histórica en la Península Ibérica [The discovery of the Middle-spotted Woodpecker in León and some notes on their historical presence in the Iberian Peninsula]. - Argutorio 12: 37-39. (in Spanish)

Robles, H. \& Ciudad, C. 2012. Influence of habitat quality, population size, patch size and connectivity on patch-occupancy dynamics of the Middle-spotted Woodpecker. - Conservation Biology 26: 284-293. DOI: 10.1111/j.15231739.2011.01816.x

Robles, C., Ciudad, C., Vera, R., Olea, P. \& Matthysen, E. 2008. Demographic responses of Middlespotted Woodpeckers (Dendrocopos medius) to habitat fragmentation. - The Auk 125: 131-139. DOI: 10.1525/auk.2008.125.1.131

Robles, H. \& Olea, P. 2003. Distribución y abundancia del pico mediano Dendrocopos medius en una población meridional de la Cordillera Cantábrica [Distribution and abundance of Middlespotted Woodpecker Dendrocopos medius in a southern population of the Cantabrian Mountains]. - Ardeola 50: 275-280. (in Spanish with English Summary)

Salas, M. Á., Ferrer, X. \& Rovira, J. V. 2005. Distribución del pico mediano en la Península Ibérica. Revisión histórica crítica (siglos XIX y XX) [Distribution of Middle-spotted Woodpecker at the Iberian Peninsula. Historical critical review (XIX and XX centuries)]. - Observatorio Medioambiental 8: 175-195. (in Spanish with English Summary)

Sansinenea, P. 1908. Catálogo descriptivo de la colección de aves é insectos legados á la Excma [Descriptive catalog of the collection of birds and insects legacies to Her Excellency]. - Diputación de Guipúzcoa por el finado D. Ángel Larrinua (q.e.p.d.). Imprenta de la Provincia, San Sebastián (in Spanish)

Saunders, H. 1884. Notes on the birds of the Pyrenees. - Ibis 26: 365-392.

Sánchez, T., González-Quirós, P. \& Vázquez, V. M. 2009. El pico mediano (Dendrocopos medius), el pico menor (Dendrocopos minor) y el picamaderos negro (Dryocopus martius), (Picidae, Aves), en el Principado de Asturias (España) [The Middle-spotted Woodpecker (Dendrocopos medius), the Lesser-spotted Woodpecker (Dendrocopos minor) and the Black Woodpecker (Dryocopus martius), (Picidae, Aves), in the Principado de Asturias (Spain)]. - Boletín de Ciencias Naturales del Real Instituto de Estudios Asturianos 50: 281-302. (in Spanish with English Summary)

Spühler, L., Krüsi, B. O. \& Pasinelli, G. 2015. Do oaks Quercus spp., dead wood and fruiting common ivy Hedera helix affect habitat selection of the Middle-spotted Woodpecker Dendrocopos medius? - Bird Study 62: 115-119. DOI: 10.1080/00063657.2014.953032

Tellería, J. L. 2004. Francisco Bernis y la ornitología española [Francisco Bernis and the Spanish Ornithology]. - In: Tellería, J. L. (ed.) La Ornitología 
hoy [Ornithology today]. - Universidad Complutense, Madrid, pp. 3-18. (in Spanish with English Summary)

Ticehurst, C. B. \& Whistler, H. 1925. A contribution to the ornithology of Navarre, Northern Spain. - Ibis 67(2): 443-460. DOI: 10.1111/j.1474919X.1925.tb02932.x

Unanue, A., Salvador, M. \& Auzmendi, G. 2010. Estudio del pico mediano (Dendrocopos medius) en el entorno de los Montes de Vitoria, Municipio de Vitoria-Gasteiz [Study of the Middle-spotted Woodpecker (Dendrocopos medius) in the vicinity of the Montes de Vitoria, Vitoria-Gasteiz Municipality]. - Unpublished report (in Spanish) Unanue, A., Salvador, M., De la Hera, I. \& Auzmendi, G. 2014. Current status of the Middle-spotted Woodpecker Dendrocopos medius in Araba (Basque Country). - In: Fernández-García, J. M., Pasinelli, G., Robles, H. \& Rubines, J. (eds.) $7^{\text {th }}$ International Woodpecker Conference. Book of Abstracts, Diputación Foral de Álava, Vitoria, p. 53.

Witherby, H. F. 1922. Dryobates medius lilianae, subsp. nov. - Bulletin British Ornithologists Club 42: 49.

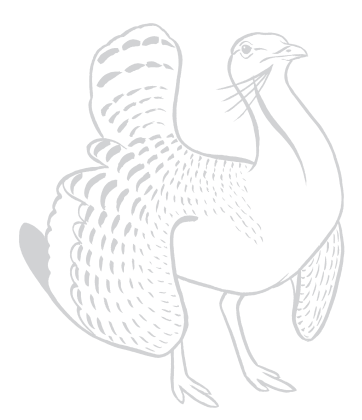

